
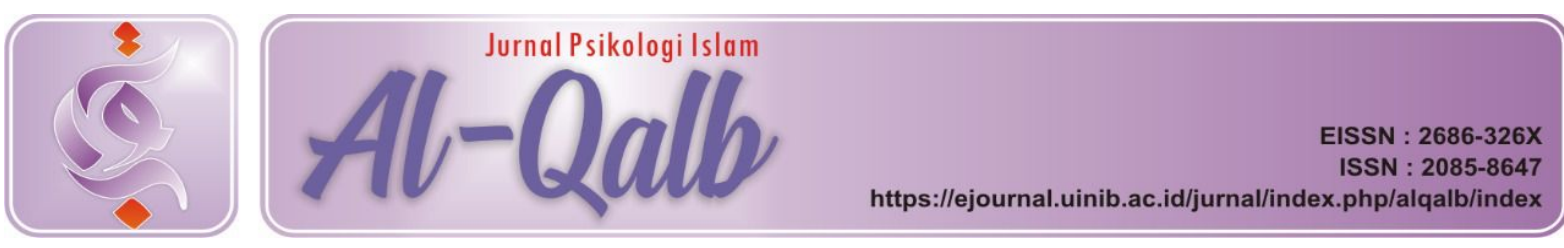

\title{
TAREKAT NAQSYABANDIYAH DAN PEMBINAAN MENTAL REMAJA
}

Received: $23^{\text {th }}$ December 2014; Revised: 08th January 2015; Accepted: $24^{\text {th }}$ February 2015

\section{Pismawenzi}

IAIN Imam Bonjol Padang

Email: pismawenzi@gmail.com

Novia Rina

IAIN Imam Bonjol Padang

\begin{abstract}
Abstrak: Kondisi emosi remaja yang mengikuti tarekat Naqsyabandiyah dapat dikontrol dengan baik. Remaja mampu mengendalikan emosi yang dimiliki ke arah yang lebih baik. Pada masa labil diusia remaja, mereka mampu mengarahkan emosi mereka ke arah yang lebih baik Kondisi pemikiran atau kognitif remaja yang mengikuti tarekat Naqsyabandiyah dapat diketahui bahwa remaja memiliki pemikiran yang positif, mereka mampu membedakan hal yang baik dan buruk untuk dilakukan, apakah memiliki dampak positif atau negatif pada diri sendiri ataupun pada orang lain. Mereka mampu memanfaatkan waktu dengan baik. Kondisi sikap remaja yang mengikuti tarekat Naqsyabandiyah ini sudah baik, dan mampu bersikap bagaimana menghadapi orang lain, sikap saling menghargai, menghormati dan saling menjaga di antara mereka dapat terjalin dengan baik dan orang- orang yang ada di sekitarnya.
\end{abstract}

Kata Kunci : Tarekat, Naqsyabandiyah, Mental Remaja

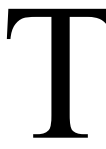
ujuan hidup sangat penting dalam menjalani kehidupan. Tanpa tujuan yang jelas, jalannya kehidupan akan mudah sekali terbawa oleh situasi sesaat. Hidup tanpa tujuan akan menim-bulkan ketidakpastian, kebingungan dan kehampaan yang pada gilirannya akan mengembangkan kehidupan tanpa makna. Kehidupan tanpa makna merupakan awal dari berbagai penderitaan. Tujuan hidup yang baik adalah sesuatu yang benar-benar didambakan dan sangat bermakna, penting dan berharga (Bastaman, 2007:223).

Tujuan hidup yang tidak jelas, membuat remaja hilang kendali dan tidak tau kemana harus ke mana perjalanan akan diarahkan. Masa yang labil ini biasanya akan mulai berakhir pada masa remaja akhir yang berkisar 17- 22 tahun. Emosi yang ditimbulkan tidak meledak-ledak lagi melainkan secara relatif telah stabil. Bila menghadapi obyek yang menyenangkan atau tidak menyenangkan bersikap atas hasil pemikiran sendiri. Pada masa pencarian identitas diri ini selama itu pula perkembangan mengalami ke-goncangan karena perubahan dalam dirinya maupun dari luar dirinya, berupa sikap orang tua, guru, cara mengajar dan masih banyak lagi serta melepaskan diri dari orang tua dan bergabung dengan teman sebaya. Apa yang dianut atau yang dipatuhi akan berubah karena berkenalan dengan nilai-nilai baru.

Zaman modern yang ditandai dengan kemakmuran material, kemajuan ilmu pengetahuan dan teknologi modern, serba mekanik dan otomatis, seringkali berdampak kepada kehidupan sejak dari sarana pemenuhan kebutuhan sehari-hari, alat transportasi, alat komunikasi, dan sarana hiburan. Pada kenyataannya, segala kemudahan, kesenangan dan kenyamanan lahiriah yang diberikan oleh materi, ilmu 
dan teknologi pada taraf tertentu menimbulkan kebosanan, tidak membawa kebahagiaan bagi hidup manusia (Majid, 1984: 71). Hal itu tidak jarang juga dirasakan dan berdampak terhadap kehidupan remaja. Remaja tidak puas dengan apa yang dimilikinya. Namun, tidak semua remaja yang memiliki prilaku buruk, pada umumnya ada remaja yang mampu mengendalikan emosinya ke arah yang lebih baik, dan memanfaatkan waktu dengan baik. Hal ini terbukti dengan adanya remaja yang mengikuti tarekat seperti tarekat Naqsyabandiyah, walaupun itu adalah suatu hal yang dianggap sulit oleh kebanyakan remaja, namun ada remaja mengikuti tarekat Naqsyabandiyah.

Tarekat merupakan suatu organisasi yang tersusun baik dalam masyarakat Islam, mempunyai pe-ngaruh kuat dan mendalam atas seluruh struktur kemasyarakatan (Majid, 1984: 11). Tarekat Naqsya-bandiyah umpamanya mengajarkan ajaran agama Islam dengan mendalam dan membina berakhlak mulia agar penganutnya menjadi insan yang taqarrub kepada Allah SWT sehingga tarekat ibarat nafas yang memberikan hidup yang pada intinya mengingat Allah SWT. Dengan mengingat Allah SWT maka mental para hamba-Nya akan tenang dan Allah akan selalu menjaga hamba-Nya. (Perpatih, 2010: 65)

\section{PEMBAHASAN}

\section{TAREKAT NAQSYABANDIYAH DAN MENTAL KEAGAMAAN}

\section{A. Tarekat Naqsyabandiyah}

\section{Pengertian Tarekat}

Secara bahasa, kata tarekat berasal dari bahasa Arab thariqah, yang berarti jalan, cara, metode, mazhab, aliran, haluan, keadaan, dan garis pada sesuatu. Dalam bahasa Indonesia telah dibakukan menjadi kata "tarekat". Jadi tarekat di sini maksudnya adalah suatu jalan atau cara yang ditempuh untuk mendekatkan diri kepada Allah.(Perpatih, 2011: 11) Menurut Harun Nasution, sebagaimana dikutip Perpatih, tarekat adalah jalan yang harus ditempuh oleh seorang calon sufi agar ia berada sedekat mungkin dengan Allah.

Ada beberapa pendapat para ahli dalam memberikan pengertian tarekat, antara lain :

a. Annemarie Schimmel menga-takan tarekat adalah "jalan" yang ditempuh para sufi dan digambarkan sebagai jalan yang berpangkal pada syariat, sebab jalan utama disebut syar' sedangkan anak jalan disebut thariq.

b. Abu Bakar Aceh mengatakan tarekat artinya jalan, petunjuk dalam melaksanakan suatu ibadah sesuai dengan ajaran yang dicontohkan oleh Nabi dan dikerjakan oleh sahabat dan tabi'in, secara turun temurun sampai kepada guru-guru, dan sambung menyambung serta rantai-berantai. Dan dapat juga dikatakan suatu cara mengajar atau mendidik, lamalama meluas menjadi kempulan kekeluargaan, yang mengikat penganutnya yang sepaham dan sealiran, guna memudahkan menerima ajaran-ajaran dan latihan-latihan dari mursyidnya.

c. Fuad Syaid, mengemukakan tarekat adalah suatu jalan atau cara mendekatkan diri kepada Allah dengan mengamalkan ilmu akidah, syaria'h dan tasawuf.

d. Imran Abu Amar, menjelaskan bahwa tarekat adalah jalan atau petunjuk dalam melaksanakan sesuatu ibadah sesuai dengan ajaran yang dibawa oleh Rasulullah dan dicontohkannya serta dikerjakan oleh para sahabatnya, tabi'in,tabi' tabi'in dan terus turun temurun sampai kepada 
guru-guru dan ulama-ulama secara bersambung dan berantai sampai masa kini (Perpatih, 2011: 12). Dari banyak defeninsi yang dikemukakan tentang pengertian dan memiliki banyak metode berbeda dalam menjalankan ritual dan cara berzikir, namun semuanya sama-sama mempunyai tujuan yang satu yakni berusaha mendekatkan diri kepada Allah SWT.

\section{Pengertian Tarekat Naqsyabandiyah}

Kata Naqsyabandi menurut Syekh Najmuddin Amin Al-Kurdi dalam kitabnya Tanwir al-Qulub, berasal dari kata Naqsy yang berarti ukiran atau gambar yang dicap pada sebatang lilin atau benda lainnya, dan kata band yang berarti bendera atau layar besar. Jadi, Naqsyabandi artinya ukiran atau gambar yang terlukis pada suatu benda, melekat, tidak terpisah lagi, seperti tertera pada sebuah bendera atau spanduk besar. Dinamakan Naqsyabandiyah dikarenakan Syekh Bahauddin pendiri tarekat ini senantiasa berzikir mengingat Allah berkepanjangan, sehingga lafadz "Allah" terukir atau melekat ketat dalam kalbunya. (Perpatih, 2011:15)

3. Sejarah Berdirinya tarekat Naqsyabandiyah

Tarekat Naqsyabandiyah ini
asal mulanya didirikan oleh Muhammad bin Bahauddin al-Uwaisi al-Bukhari (717-791 H). Biasa disebut sebagai Naqsyabandi diambil dari kata Naqsyaband yang berarti lukisan, karena ia ahli dalam memberikan lukisan kehidupan yang ghaib-ghaib sebagaimana dibaca dalam buku The Darvishes karangan J.P. Brown. Tarekat Naqsyabandiyah ini berhubungan langsung kepada Nabi
Muhammad sebagaimana diterangkan dalam silsilahnya oleh Muhammad Amin al-Khurdi dalam kitabnya Tanwirul Qulub. Katanya, bahwa Naqsyabandi memperoleh terikat ini dari Amir Kulal bin Hamzah dari Muhammad Baba Assammasi dari Ali ar-Ramitni yang mashur dengan nama Syekh Azizan, dari mahmud alFughnawi, dari Arif ar- Riyukri, dari Abdul Khalik Al-Khujdawani dari Abu Yakub Yusuf al-Hamdani dari Abu Ali al-Fadhal bin Muhammad At-Thusi AlFarmadi dari Abdul Hasan Ali bin Ja'far al-Khirqani dari Abu Yazid alBisthami, dari Imam dari Qasim bin Muhammad anak Abu Bakar Assiddiq dan Abu Bakar menerima langsung dari Muhammad yang dicurahkan melalui Malaikat Jibril oleh Allah SWT.

Tarekat Naqsyabandiyah tersebar di Sumatera, Jawa, maupun Sulawesi. Umpamanya di Sumatera Barat, di daerah Minangkabau tarekat ini tersiar terutama atas jasa Syekh Ismail al- Khalidi al-Kurdi, sehingga terkenal dengan sebutan tarekat Naqsyabandiyah Khalidiyah.

Tarekat ini asal mulanya didirikan oleh Muhammad bin Bahauddin al-Uwaisi al-Bukhari (717791 H).Biasa disebut dengan Naqsyaband yang berarti lukisan, karena ia ahli dalam memberikan lukisan kehidupan yang ghaib-ghaib. Tarekat Naqsyabandiyah ini memiliki kedudukan yang istimewa karena berasal dari Abu Bakar dan mengenai diri Abu Bakar, Nabi Muhammad pernah bersabda, "Tidak ada sesuatupun yang dicurahkan Allah dalam dadaku melainkan aku mencurahkannya kembali ke dalam dada Abu Bakar.(Proyek Pembinaan Perguruan Tinggi IAIN Sumut, 1983: 285)

$\begin{array}{cc}\text { Tarekat } & \text { Naqsyabandiyah } \\ \text { memiliki ciri yang menonjol yaitu }\end{array}$


mengikuti syaria't secara ketat, keseriusan dalam beribadah dan lebih menyukai berzikir dalam hati. Upaya yang ditunjukkan tarekat Naqsyabandiyah banyak terlihat dalam mempengaruhi kehidupan dan pemikiran golongan penguasa serta mendekatkan negara pada agama (Mulyati, 2006: 91).

Dari silsilah yang diketahui bahwa Tarekat Naqsyabandiyah Jorong II Sungai Pandahan ini didirikan oleh Syekh Bahauddin yang datang dari Negara Turki, kemudian dikembangkan dan diturunkan kepada para muridnya, salah satu muridnya adalah Syekh Maulana Ibrahim yang makamnya sekarang ada di surau Batu Kumpulan di kabupaten Pasaman kemudian dikembangkan dan diturunkan kepada muridnya. Salah satu muridnya adalah Syekh Surimi dan diturunkan kepada anaknya yang bernama $H$. Zainal Tungko Tuo. Tarekat ini sudah dikembangkan pada masa penjajahan Belanda dan masa penjajahan Jepang di daerah Sumatera Barat. Tarekat ini merupakan ajaran Rasulullah yang dibawa oleh Abu Bakar As-shiddiq dan dikembangkan kepada para sahabat dan para wali sampai kepada para syekh dan diterima oleh masyarakat sekarang ini.

4. Ajaran Tarekat Naqsyabandiyah

Tata cara pelaksanaan tarekat antara lain :

a. Zikir, yaitu megingat terus-menerus kepada Allah dalam hati serta menyebutkn namanya dengan lisan. Zikir ini berguna sebagai alat kontrol bagi hati, ucapan dan perbuatan agar tidak menyimpang dari garis yang sudah ditetapkan Allah.

b. Ratib, yaitu mengucap lafal $L a$ ilaha illa Allah dengan gaya, gerak dan irama tertentu. c. Muzik, dalam membacakan wiridwirid dan syair-syair tertentu diiringi dengan bunyi-bunyian seperti memukul rebana. Ini tidak ada dilakukan di tarekat Naqsyabandiyah Jorong II Sungai Pandahan kabupaten Pasaman.

d. Menari, yaitu gerak yang dilakukan mengiringi wirid-wirid dan bacaanbacaan tertentu untuk menimbulkan kekhidmatan. Ini juga tidak ada dilakukan dalam tarekat Naqsyabandiyah Jorong II Sungai Pandahan kabupaten Pasaman.

e. Bernafas, yaitu mengatur cara bernafas pada waktu melakukan zikir yang tertentu (Nata, 2010: 227).

Abdul Hakim Hassan, sebagaimana yang dikutip Simuh menyebutkan bahwa tarekat pada dasarnya terdiri dari dua bagian. Pertama mujahadah yang berupa renungan bathin, dan kedua riyadhat atau latihan rohani yang ditentukan dan diatur oleh para sufi sendiri.

Bagian pertama (renu-ngan bathin) merupakan renungan falsafi, yang terdiri dari mawas diri, penguasaan nafsu-nafsu, pembinaan akhlak mulia, dan memuncak pada pember-sihan hati dan keinginan hanya pada Allah saja. Bagian kedua lebih bersifat praktis, berisi teknik-teknik meditasi dengan media zikir dan wiridwirid lain secara praktis. Oleh karena itu memungkinkan untuk diikuti oleh orang awam secara massa.(Tiswarni, 2007:134-143).

Dalam tarekat Naqsya-bandiyah di Jorong II Sungai Pandahan ini diberikan riyadhat dan mujahadah kepada muridnya untuk mencapai tujuan mende-katkan diri kepada Allah SWT menjadi insan yang bersih dan selalu mengingat Allah dan sadar akan dirinya sebagai hamba Allah. Tarekat ini dilakukan pada malam hari mulai 
pukul 23.00 WIB sampai dini hari. Setelah shalat isya Mursyid dan para murid hanya bercerita atau cera-mah dan nasehat yang disam-paikan oleh Mursyid. Ketika Guru memerintahkan untuk memulai zikir murid berwudhuk terlebih dahulu sebelum mengi-kuti zikir, bagi laki-laki meng-gunakan peci, baju dan celana berwarna putih. Perempuan memakai mukena berwarna putih. Murid dikelompokkan berdasarkan tingkatan zikirnya, Mursyid selalu mengawasi apa-pun yang dilakukan para murid-nya, sehingga tidak ada murid yang bisa lengah ataupun tertidur dari tugasnya untuk berzikir kepada Allah.

Tingkatan dasar pada zikir ini disebut dengan zikir keras, dengan mengucapkan lafdz Lailahaillallah sebanyak mung-kin tanpa terhitung sampai guru menyuruh untuk berhenti dengan mengeraskan seluruh anggota badan dengan duduk bersila. Setelah melalui zikir dasar dilanjutkan untuk zikir latifah dengan masing-masng zikirnya 1000x dan kemudian dilanjutkan untuk melakukan fidiyah sampai $7000 x$ masing-masing latifah sama dengan 20 hari suluk. Zikir ini dilatih mulai dari lisan, kemudian mengingat hanya Allah sehingga lafadz Allah menyatu dengan hati seseorang, hal ini yang dilatih pada murid dalam tarekat Naqsyabandiyah ini.

Latifah yang dilakukan murid ini ada tujuh latifah yang terdiri dari latifatul Kalbi, latifatul Roh, latifatul Sir, latifatul Affa, Latifatul Affi, latifatul Nafsul Natakah, dan Latifatul Kullu Jasad. Masing-masing latifah ini dilakukan dengan posisi duduk berbeda, dengan hitungan 1000x sampai 7000x masing-masing latifah. ini dilakukan oleh murid sesuai dengan arahan dari guru. Dengan menyebut nama Allah untuk melatih lahir dan bathiniah untuk selalu merasa dekat dengan Allah SWT.
Setelah melewati zikir latifah murid melanjutkan zikirnya hanya dengan mengingat Allah saja tanpa menggunakan tasbih, ini tingkatan yang lebih tinggi. Ini biasa disebut wukuf dalam tarekat ini, hanya mengatur nafas dengan mengingat Allah tanpa ada bergerak sedikitpun. Ini dilakukan dalam suluk maupun tidak. Melanjutkan tingkat yang lebih tinggi lagi ini dirahasiakan hanya bagi orang yang melewati ini yang bisa mengetahuinya. Ini dilatih secara terus menerus pada murid sehinga lafadz Allah menyatu dalam hati mereka, sehingga emosional, kognitif dan sikap dapat dipengaruhi ke arah yang lebih baik yang memberikan energi positif.

5. Tujuan dan fungsi dari Tarekat Naqsyabandiyah

$\begin{array}{lcr}\text { Tarekat di kalangan } & \text { sufiyah } \\ \text { berarti } & \text { sistem } & \begin{array}{c}\text { dalam } \\ \text { rangka }\end{array} \\ \text { mengadakan } & \text { latihan } & \text { jiwa, }\end{array}$
membersihkan diri dari sifat-sifat tercela dan mengisinya dengan sifatsifat yang terpuji dan memperbanyak zikir dengan penuh ikhlas semata-mata untuk mengharapkan bertemu dengan dan bersatu secara ruhiah dengan Tuhan. Jalan tarekat itu antara lain terus menerus berada dalam zikir atau ingat terus kepada Tuhan, dan terusmenerus menghindarkan diri dari sesuatu yang melupakan Tuhan. Tujuan dari tarekat adalah jalan yang bersifat spritual bagi seorang sufi yang di dalamnya berisi amalan ibadah dan lainnya yang bertemakan menyebut nama Allah dan sifat-sifatNya disertai dengan penghayatan yang mendalam. Amalan dalam sifat-Nya ini ditujukan untuk memperoleh hubungan sedekat mungkin secara rohaniah dengan Tuhan (Tiswarni, 2007:271).

Tujuan dari tarekat Naqsyabandiyah ini untuk mencapai Tuhannya yaitu Allah SWT, benar- 
benar merasakan bahwa Allah itu ada dan bersamanya. Riyadhat dan Mujahadah ini merupakan cara untuk mewujudkan tujuan yang diinginkan. Bahwa tujuan yang selama ini dicari adalah ridha Allah. Maksud dan tujuan hanyalah Allah SWT.

\section{B. Mental Keagamaan}

1. Pengertian Mental Keagamaan

Zakiah Daradjat mengata-kan bahwa dalam ilmu pskiatri dan psikoterapi, mental diguna-kan sebagai kata ganti dari kata personality atau kepribadian yang berarti bahwa mental dalam unsur-unsur jiwa termasuk pikiran, emosi, sikap dan perasaan yang dalam keseluruhan akan menentukan corak tingkah laku, cara menghadapi sesuatu hal yang menekan perasaan, menge-cewakan, menggembirakan atau menyenangkan dan sebagainya. (Daradjat, 1982: 38-39)

Secara prinsip mental mempunyai pengertian sama dengan jiwa, nyawa, roh dan semangat. Seseorang yang sehat mental memiliki karakter utama. (Perpatih, 2011: 12), yaitu se-bagai berikut :

a. Sikap kepribadian yang baik terhadap diri sendiri dalam arti dapat mengenal diri dengan baik.

Seseorang menyadari bahwa tubuh dan roh memiliki hak yang harus dipenuhi, ketika tubuh letih, maka tubuh butuh istirahat. Begitu juga dengan jiwa manusia, butuh pembinaan dan nasehat sebagai peringatan untuk manusia yang lalai.

b. Pertumbuhan, perkemba-ngan dan perwujudan diri yang baik.

Pertumbuhan dan perkembangan yang dilalui sesuai dengan kepribadian yang dimi-liki. Pada masa pertumbuhan remaja dimana adanya masa perubahan fisik, dan perubahan prilaku dan emosi yang labil, akan terlihat bagaimana remaja menyikapi halhal yang terjadi pada dirinya.

c. Integrasi diri, yang meliputi keseimbangan mental, kesatuan pandangan, dan tahan terhadap tekanan-tekanan yang terjadi.

Dalam kehidupan manusia tidak luput dari masalah-masalah yang butuh pemecahan dengan bijaksana tanpa ada yang dirugikan. Tidak ada manusia yang tidak memiliki masalah. Namun, akan terlihat mental manusia yang sehat dan seimbang dari kemampuan seseorang dalam mengendalikan diri, emosi dan menyelesaikan permasa-lahan dengan bijaksana.

d. Otonomi diri yang mencakup unsur-unsur pengatur kelakuan diri dalam atau kelakuan-kelakuan bebas.

Remaja yang menya-dari bahwa kehidupan yang dilalui memiliki aturan-aturan tertentu yang harus dipatuhi dan diaplikasikan dalam keseharian. Bahwa agama mengatur prilaku manusia untuk kepentingan dan keselamatan dari manu-sia itu sendiri sehingga tidak bertindak semena-mena.

e. Persepsi mengenai realitas, bebas dari penyimpangan kebutuhan, serta memiliki empati dan kepekaan sosial.

Remaja yang peduli dengan sesama maka akan memberikan kedamaian dalam kehidupan, karena penerus dari kehidupan adalah para remaja. Tolong menolong akan terhindar dari kecemburuan antar sesama, bahwa dalam kehidupan ini Allah menyeimbangkan, ada yang kaya ada yang miskin, yang kaya untuk menolong yang miskin, dan ada 
yang kuat untuk membela yang lemah.

Maka mental agama merupakan prinsip keper-cayaan kepada Tuhan dengan aturanaturan syariat tertentu. Mendapat awalan ke- dan akhiran -an menjadi keagamaan yang berarti segala hal yang berkaitan dengan agama.(Tim Prima Pena, tt: 20) Suatu hal yang penting diketahui dalam agama adalah rasa pengabdian, setiap penganut agama merasa, bahwa ia harus cinta dan mengabdikan diri dengan seluruh kemam-puannya kepada agama yang dipeluknya. (Fauzi, 2007: 2) Agama hanya bisa dirasakan dengan hati, pikiran dan dilaksanakan dalam tindakan serta memantul dalam sikap dan cara menghadapi hidup. (Daradjat, 2005: 5)

Mental keagamaan dapat diartikan bagaimana jiwa manusia dalam menjalani kehidupan dan pengabdiannya terhadap agama yang dianutnya sesuai dengan syariat yang telah ditentukan. Bagaimana pengaruh keyakinan agama dalam bersikap, bertingkah laku dan keadaan hidup yang dihadapi. Berkaitan erat dengan ilmu jiwa agama menurut Zakiyah Darajat yaitu bagaimana pengaruh agama terhadap sikap dan tingkah orang atau meka-nisma yang bekerja dalam diri seseorang, karena cara seseorang berpikir, bersikap, bereaksi, dan bertingkah laku, tidak dapat dipisahkan dari keyakinannya, karena keyakinan itu masuk dalam konstruksi kepribadiannya. (Daradjat, 2005: 4)

2. Perkembangan Mental Keagamaan Remaja

Remaja menurut Piaget adalah individu yang berumur berkisar antara
10 sampai 20 tahun dimana individu diha-rapkan mampu menemukan siapa mereka, mereka sebe-tulnya siapa, dan kemana me-reka menuju dalam hidupnya. (Taylor,dkk, 2009: 350) Hal ini menyebabkan ada remaja yang berusaha mencari jati diri dengan cara yang salah atau negatif dan ada dengan cara yang positif seperti mengembangkan kreatifitas dan ada remaja yang memasuki tarekat. Fase remaja merupakan segmen perkembangan individu yang sangat penting yang diamati dengan matangnya organ-organ fisik atau seksual sehingga mampu berpro-duksi. Menurut Konopka (Pikunas,1976) masa remaja meliputi :

a. Remaja awal 12-15 tahun

b. Remaja Madya 15-18 tahun

c. Remaja akhir 19-22 tahun

Sementara Salman mengemukakan bahwa remaja merupakan masa perkem-bangan sikap tergantung ter-hadap orang tua kearah kemandirian, minat seksual, perenungan diri. Dalam budaya Amerika, periode remaja ini dipandang sebagai masa "Strom dan Stress", frustrasi dan penderitaan, konflik dan krisis penye-suaian, mimpi dan melamun tentang cinta, dan perasaan tereliminasi atau tersisihkan dari kehidupan sosial budaya orang dewasa.(Yusuf, 2005, 184) Remaja menganggap bahwa beribadah belum tiba waktu bagi mereka, masa tua belum datang, sehingga prilaku remaja susah untuk dikendalikan. Pada masa remaja ini merupakan masa pada emosi yang labil, masih berada dalam pengawasan orang tua dan orang-orang terdekat.

Pada usia ini, remaja berada dalam berbagai gejolak perasaan, senang, sedih, gembira, bangga, kecewa, frustasi, bersemangat, atau putus asa. Pada umumnya remaja 
memiliki dorongan seksual yang kuat. Hal ini disebabkan terjadinya perubahan hormo-nal yang membuat mereka memiliki dorongan seksual yang kuat sehingga harus ditanggapi dengan sikap yang wajar. (Subakti,2009: 1) Bahkan terlihat jelas shalat berjamaah di mesjid hanya diisi oleh golongan orang tua dan golongan muda mengisi acara-acara pesta atau kegia-tan duniawi. (Ahmad, 2006: 135) Hal ini juga ditemukan di Jorong II Sungai Pandahan kabupaten Pasaman bahwa hanya golongan orang tua yang mengisi mesjid pada saat shalat berjemaah, dan remaja hanya berkumpul di halaman mesjid sambil terta-wa bersama-sama. Banyak orang tua yang mengeluh, bahkan bersusah hati, karena anak-anaknya yang telah remaja menjadi keras kepala, sukar diatur, mudah tersing-gung, sering melawan, sering bertengkar, membuat kela-kuan-kelakuan yang melang-gar aturan atau melanggar nilai-nilai moral dan norma-norma agama. (Daradjat, 2005: 81) Hal ini juga dialami oleh masyarakat dan orang tua remaja di Jorong II Sungai Pandahan kabupaten Pasaman tentang perihal remaja yang memiliki sikap buruk dan prilaku yang tidak dapat dikontrol dengan baik.

Kata bina atau membina
menurut Kamus Besar Bahasa Indonesia adalah membangun, mengusahakan menjadi lebih baik, mengupayakan agar sedikit lebih maju dan sempurna. (Tim Prima Pena, tt: 146) Secara etimologis kata bimbingan merupakan terjemahan dari kata guedance, berasal dari kata kerja to guide, yang mempunyai arti menunjukkan, membimbing, menuntun, membina ataupun membantu. Sesuai dengan istilahnya ma-ka secara umum bimbingan dapat diartikan pembinaan yang merupakan proses yang berkesinambungan, sehingga bantuan itu diberikan secara sistematis, berencana terus menerus dan terarah kepada tujuan tertentu. Dengan demikian kegiatan pembinaan bukanlah kegiatan yang dilakukan secara kebetulan, insendental, sewaktu-waktu, tidak disengaja atau kegiatan yang asalasalan.(Hallen, 2005: 1-5) Jadi pembinaan merupakan upaya serius yang berkesinambungan untuk membimbing individu dalam rangka mencapai tujuan yang diinginkan.

Pada dasarnya perma-salahan pembinaan mental beragama tidak bisa dilepas-kan dari pembinaan kepribadian secara keseluruhan. Karena beragama itu adalah bagian dari kehidupan itu sendiri, sikap atau tindakan seseorang dalam hidupnya tidak lain dari pantulan pribadinya yang tumbuh dan berkembang sejak lahir, bahkan sudah mulai sejak dalam kandu-ngan. Semua pengalaman yang dilalui sejak dalam kandungan, mempunyai pe-ngaruh terhadap pembinaan pribadi. Masalah akidah, ibadah, akhlak dan muamalah sesuai dengan pembidangan Islam itu sendiri sebagai suatu sistem agama. Dimana dalam bidang akidah antara lain tentang iman kepada Allah, malaikatmalaikatNya, kitab-kitabNya, rasulrasul-Nya, hari akhir dan iman kepada taqdir. Permasalahan dalam bidang ibadah antara lai tentang taharah, syahadat, shalat, puasa, zakat, haji, doa dan zikir, dan membaca alqur'an dan sebagainya. Permasalahan dalam bidang akhlak antara lain tentang kemauan untuk berakhlak dan permasalahan dalam bidang muamalah antara lain tentang bimbingan keserasian, kesela-rasan, dan keseimbangan hu-bungan manusia dan kehidu-pannya. (Jaya, 2000: 4) Pemahaman yang sedemikian hanya dimiliki remaja sebatas pengalaman dan peneriman sepanjang 
kehidupannya. Maka pembinaan yang lebih dibutuhkan oleh remaja untuk menghadapi masa pertum-buhan selanjutnya menjadi pribadi yang dewasa.

Pembinaan sebagai proses pemberian bantuan yang dilakukan oleh orang yang ahli kepada seseorang atau beberapa orang, baik anak-anak, remaja, maupun dewasa, agar yang dibina dapat mengembangkan kemampuandan potensi yang dimiliki dan mandiri, dengan memanfaatkan kekuatan in-dividu dan sarana dan dapat dikembangkan berdasarkan norma-norma dan aturan yang berlaku.

Pembinaan mental keagamaan adalah bantuan yang diberikan kepada sese-orang untuk pencegahan munculnya masalah pada jiwa mereka. Dengan demi-kian pembinaan mental keagamaan remaja merupa-kan proses untuk membantu remaja agar memahami bagaimana ketentuan dan petunjuk Allah tentang kehi-dupan beragama, menghayati ketentuan dan petunjuk tersebut, mampu menjalan ketentuan petunjuk Allah dengan benar dalam Agama Islam yang bersangkutan akan bisa hidup bahagia dunia dan akhirat dan mampu menyesuaikan diri dengan diri sendiri dan masyarakat. Mereka juga diharapkan mampu menghindari resiko menghadapi masalah-masalah yang berkenaan dengan keagamaan seperti kafir, syirik, munafik, tidak mau menjalankan perintah Allah dan sebagainya.

Jika dilihat pada mental keagamaan remaja, ada sifat yang baik dan buruk. Apabila iman dihatinya kuat maka mental atau jiwanya akan baik, tetapi sebaliknya jika imannya lemah atau rapuh maka mental atau jiwanya bisa menjadi buruk.

Pembinaan kehidupan

beragama pada remaja tidak dapat dilepaskan dari pem-binaan kepribadian secara ke-seluruhan. Karena kehidupan beragama itu adalah bagian dari kehidupan itu sendiri, sikap atau tindakan seseorang dalam hidupnya tidak lain dari pantulan pribadinya yang bertumbuh dan berkembang sejak lahir. (Daradjat, 2005:139).

Banyak pembinaan mental yang diberikan oleh orang tua dan masyarakat kepada remaja di Jorong II Sungai Pandahan kabupaten Pasaman seperti wirid-wirid pengajian, penyambutan hari-hari besar agama Islam, ajakan untuk melaksanakan shalat jumat secara rutin, shalat hari raya, namun semua pembinaan itu tidak berjalan seperti yang diha-rapkan. Banyak dari remaja tidak menghiraukan pembi-naan yang seperti itu, sehingga tidak mendapatkan hasil yang memuaskan bahkan hanya ada penurunan. Untuk itu diperlukan pembinaan yang khusus pada remaja untuk mampu mengendalikan dirinya dan mengontrol emosi menjadi lebih baik. Mengetahui bagai-mana bersikap yang baik kepada orang lain dan bagaimana berpikir positif. Dengan demikian diharapkan dengan adanya tarekat Naqsyabandiyah ini maka remaja mampu mengatasi masa transisinya yang penuh gejolak perasaan dan bisa terkontrol dengan baik.

Perkembangan

mental keagamaan pada remaja ditandai oleh beberapa faktor.. Perkembangan itu adalah antara lain menurut W. Starbuck sebagaimana dikutip Jalaluddin (2010: 74) adalah :

a. Pertumbuhan Pikiran dan Mental

Ide dan dasar keyakinan beragama yang diterima remaja dari masa kanak-kanaknya sudah tidak begitu menarik bagi mereka. Sifat kritis terhadap agama sudah mulai timbul.

b. Perkembangan Perasaan 
Berbagai perasaan telah berkembang pada masa remaja. Perasaan sosial, etis mendorong remaja untuk menghayati perikehidupan yang terbiasa dalam lingkungannya. Kehidupan religius akan cenderung mendorong dirinya lebih dekat kearah hidup yang religi.

c. Pertimbangan Sosial

Corak keagamaan para remaja juga ditandai oleh adanya pertimbangan sosial. Dalam kehidupan keagamaan mereka timbul konflik antara pertimbangan moral dan material. Remaja bingung menetukan pilihan itu. Karena kehidupan duniawi lebih dipengaruhi kepentingan akan materi, maka para remaja lebih cenderung jiwanya untuk bersikap materialis.

d. Perkembangan moral

Perkembangan moral para remaja bertitik tolak dari rasa berdosa dan usaha untuk mencapai proteksi.

e. Sikap dan minat

Sikap dan minat remaja terhadap masalah keagamaan boleh dikatakan sangat kecil dan hal ini tergantung dari kebiasaan masa kecil serta lingkungan agama yang mempengaruhi mereka.

Ini merupakan ciri-ciri perkembangan mental keaga-maan yang dialami oleh remaja yang mengalami masa penuh dengan gejolak perasaan yang tidak menentu. Perkembangan mental keaga-maan remaja ini mencakup pertumbuhan pikiran, mental, perkembangan perasaan, pertimbangan sosial, moral, sikap dan minat remaja. Terpenuhinya semua faktor perkembangan mental keagamaan remaja memiliki mental keagamaan yang baik.

\section{METODE}

Penelitian ini adalah kuali-tatif. Adapun sumber data dalam penelitian ini adalah: data primer 4 remaja untuk dijadikan sumber data utama (3 orang lakilaki dan 1 orang perempuan). Rentang usia remaja ini berkisar antara 19-22 tahun. Data sekunder merupakan sumber data pendukung dalam penulis ini. Dalam hal ini penulis meminta kepada orang-orang terdekat dari remaja seperti orang tua, teman-teman, guru /mursyid yang membimbing remaja dalam tarekat Naqsyabandiyah serta masyarakat.

Penelitian ini dilakukan di Jorong II Sungai Pandahan, kenagarian Sundata, kecamatan Lubuk Sikaping, kabupaten Pasaman Timur.

Teknik pengumpulan data yang digunakan dalam penelitian ini adalah observasi Data observasi yang diperoleh dalam penelitian ini terkait dengan bagaimana peranan tarekat naqsyabandiyah dalam membina perilaku keagamaan remaja di Jorong II di Sungai Pandahan Kenagarian Sundata, kecamatan Lubuk Sikaping, Kabupaten Pasaman Timur. Selanjutnya metode wawancara. Metode ini untuk mengetahui manfaat, kendala, pengaruh dalam kognitif, afektif dan prilaku dari remaja yang mengikuti tarekat Naqsyabandiyah.

Untuk mendapatkan data yang shahih tentang peranan tarekat Naqsyabandiyah terhadap pembinaan mental keagamaan remaja di Jorong II Sungai Pandahan Kenagarian Sundatar kec. Lubuk Sikaping, Kab. Pasaman. peneliti menggunakan uji kredibilitas penelitian dengan perpanjangan pengamatan, meningkatkan ketekunan, dan triangulasi (waktu, sumber dan metode).

\section{Kondisi Mental Keagamaan Remaja yang Mengikuti Tarekat Naqsyabandiyah}




\section{A. Kondisi Emosional Remaja yang Mengikuti Tarekat Naqsyabandiyah}

Dari hasil wawancara dan observasi terhadap beberapa subjek ,tentang peranan tarekat Naqsya-bandiyah terhadap pembinaan mental keagamaan remaja maka dapat disimpulkan bahwa remaja mampu mengontrol emosinya menjadi lebih baik, berpikir positif terhadap suatu hal, karena subjek menyadari bahwa emosi yang tidak terkendali memiliki banyak resiko dan dampak yang negatif, baik resiko terhadap diri sendiri ataupun terhadap orang lain atau lingkungannya. Pengontrolan emosi subjek ini memberikan ketenangan hati dan mampu berpikir jernih apabila menghadapi suatu permasalahan. Remaja menjadi lebih baik dari sebelumnya yang terlihat dari sikap dan tingkah lakunya dalam hidup di tengah keluarga dan masyarakat pada umumnya.

Berdasarkan wawancara dan hasil observasi yang dilakukan maka dapat disimpulkan bahwa subjek mampu mengontrol emosinya dengan baik karena subjek menyadari bahwa emosi yang tidak terkendali memiliki banyak resiko dan dampak yang negatif. Dari wawancara yang dilakukan dapat disimpulkan bahwa subjek memiliki pengontrolsn emosi yang baik, dapat mengarahkan emosinya ke arah yang lebih baik, mampu memanfaatkan waktu dengan baik dan bermanfaat. Subjek dapat mengkontrol emosi marah dengan baik, rasa cinta dan rasa takut dari subjek bisa diarahkan ke arah yang lebih baik dan bermanfaat.

\section{B. Kondisi Pikiran atau Kognitif Remaja yang Mengikuti Tarekat Naqsyabandiyah}

Berdasarkan wawancara dan observasi yang dilakukan terhadap subjek pertama, maka dapat disimpulkan bahwa subjek memiliki nalar yang baik. Subjek memiliki kognitif yang baik dan tidak menghabiskan waktu dengan sia-sia. Subjek mampu membedakan apa yang baik dan tidak baik untuk dilakukan. Mampu berpikir positif terhadap suatu permasalahan.

Berdasarkan wawancara dan hasil observasi yang dilakukan Tentang peranan tarekat Naqsya-bandiyah terhadap pembinaan mental keagamaan remaja maka dapat disimpulkan bahwa subjek memiliki nalar yang baik meskipun subjek tidak memiliki banyak pertanyaan terhadap isi materi yng disampaikan oleh gurunya. Subjek memiliki pikiran atau kognitif yang baik, subjek mampu membedakan mana yang baik dan buruk untuk dilakukan, subjek juga sudah bisa mengatur waktu menjadi lebih baik, kapan waktu untuk bermain, belajar dan membantu orang tua. Hal ini menunjukkan subjek memiliki perubahan ke arah yang positif setelah mengikuti tarekat Naqsya-bandiyah.

Berdasarkan hasil wawancara dan observasi yang dilakukan tentang peranan tarekat Naqsyabandiyah terhadap pembinaan mental keagamaan remaja maka dapat disimpulkan bahwa subjek memiliki nalar yang baik, memiliki pemikiran positif dan jauh ke depan. Subjek mampu membedakan apa yang baik dan buruk, mampu mengarahkan pemikiran ke arah yang lebih baik. Subjek juga mampu memanfaatkan waktunya menjadi lebih baik, ketika libur dimanfaatkan untuk membantu orang tua, dan mencari uang sendiri untuk tambahan uang jajan sekolahnya.

Berdasarkan hasil wawancara dan observasi yang dilakukan tentang peranan tarekat Naqsyabandiyah terhadap pembinaan mental keagamaan remaja maka dapat disimpulkan bahwa subjek memiliki nalar yang baik, subjek memiliki pemikiran positif terhadap suatu hal dan subjek termasuk pada anak remaja yang aktif dan kreatif. Subjek mampu berprasangka baik dan memanfaatkan sesuatu menjadi lebih baik. Subjek tidak mengenal kata putus asa tetapi subjek tetap semangat dan lebih giat lagi untuk meraih 
kesuksesan. Subjek berpikir positif dan berpikir kedepan untuk bisa mendapat kesuksesan dan berguna dan mampu membuat bangga kedua orang tuanya.

\section{Kondisi Sikap Remaja yang Mengikuti Tarekat Naqsya-bandiyah}

Berdasarkan wawancara dan hasil observasi yang dilakukan tentang peranan tarekat Naqsyabandiyah terhadap pembinaan mental keagamaan remaja maka dapat disimpulkan bahwa subjek memiliki sikap yang baik, tidak melakukan hal-hal yang bisa merugikan diri sendiri ataupun orang lain. Subjek mampu bersikap dengan baik, menghargai, menghormati orang lain, tidak membantah orang tuanya, mampu mengontrol emosi, sehingga subjek mampu bersikap dengan baik.

\section{SIMPULAN}

\section{DAFTAR RUJUKAN}

Bastaman , HD. Logoterapi, psikologi untuk menemukan makna hidup dan meraih hidup bermakna, Jakarta: PT.RajaGrafindo Persada, 2007.

Departemen Agama RI, Al-Qur'an dan Terjemahannya, Jakarta: Gema Risalah Press bandung, 1989.

Drajat, Zakiah. Ilmu Jiwa Agama, PT. Bulan Bintang : Jakarta, 2005.

Dradjat, Zakiyah. Kesehatan Mental Peranannya dalam Pendidikan dan Pengajaran, Jakarta: IAIN Sahid, 1984.

Fauzi, Muhammad. Agama dan Realitas Sosial Renungan dan Jalan menuju
1. Kondisi emosi remaja yang mengikuti tarekat Naqsyabandiyah dapat dikontrol dengan baik. Remaja mampu mengendalikan emosi yang dimiliki ke arah yang lebih baik. Pada masa labil diusia remaja, mereka mampu mengarahkan emosi mereka ke arah yang lebih baik

2. Kondisi pemikiran atau kognitif remaja yang mengikuti tarekat Naqsyabandiyah dapat diketahui bahwa remaja memiliki pemikiran yang positif, mereka mampu membedakan hal yang baik dan buruk untuk dilakukan, apakah memiliki dampak positif atau negatif pada diri sendiri ataupun pada orang lain. Mereka mampu memanfaatkan waktu dengan baik.

3. Kondisi sikap remaja yang mengikuti tarekat Naqsyaban-diyah ini sudah baik, dan mampu bersikap bagaimana menghadapi orang lain, sikap saling menghargai, menghormati dan saling menjaga di antara mereka dapat terjalin dengan baik dan orang- orang yang ada di sekitarnya.

Kebahagiaan, PT.RajaGrafindo Persada : Jakarta, 2007.

Hallen, Bimbingan Konseling, Jakarta :Quantum Teaching, 2005.

http://www.masbied.com/2009/12/24/peng ertian-pembinaan-mental/

http://id.shvoong.com/humanities/theorycriticism/2165744-definisi-peranatau-peranan/

Jalaluddin, Psikologi Agama, PT.RajaGrafindo Persada : Jakarta, 2010.

Jaya, Yahya. Bimbingan Konsling Agama Islam, Padang : Angkasa Raya, 2000 . 
52 Jurnal Al-Qalb, Jilid 7, Nomor 1, Maret 2015, hlm. 40-52

Kahmad, Dadang. Sosiologi Agama, Bandung: PT. Remaja Rosdakarya, 2006.

Kartanegara, Mulyadhi. Menyelami Lubuk Tasawuf, Pondok Petir: PT. Gelora Aksara Pratama, 2006.

Langgulung, Hasan. Pendidikan Islam dan Peralihan Paragdima, selangor : Hizbi, 1995.

Madjid, Nurcholish. Warisan Intelektual Islam, Khasanah Intelektual Islam, Jakarta : Bulan Bintang, 1984.

Mujib, Abdul \& Mudzakir, Yusuf. Nuansa-Nuansa Psikologi islam, Jakarta : PT.Raja Grafindo Persada, 2001.

Mulyati, Sri. Mengenal dan memahami Tarekat-tarekat Muktabarah di Indonesia, Jakarta:Kencana,2006.

Nata, Abudidin. Akhlak Tasawuf, Jakarta:PT.RajaGrafindo Persada,2010.

Parpatih, Sy. Dt Suluk dan Kesehatan Mental, Padang: Hayfa Press, 2010.

Poerwandari, Kristi. pendekatan Kualitatif,penelitian prilaku manusia, Jakarta:LPSP3 UI,2005.

Poewardinata, Wjs. Kamus Umum Bahasa Indonesia, Jakarta : Balai Pustaka, 1976.
Proyek Pembinaan Perguruan Tinggi Agama Institut Agama Islam Negeri Sumatera Utara, Pengantar Ilmu Tasawuf, Jakarta, 1983.

Rumini, Sri. Perkembangan Anak dan Remaja, Jakarta : PT. Rineka Cipta, 2004.

Sugiyono, Metode Penelitian Kuantitatif,Kualitatif DAN $R \& D$, Bandung: Penerbit Alfabeta, 2011.

Sukmono, Rizki Joko Psikologi Zikir, Jakarta: PT. RajaGrafindo Persada, 2008.

Surbakti, E.B, Kenalilah Anak Remaja Anda, Jakarta: PT. Elex Media Komputindo, 2009.

Tiswarni, Akhlak Tasawuf, Jakarta: Safira Jakarta, 2007.

Tim Prima Pena, Kamus Besar bahasa Indonesia, Gita Media Press.

Taylor,E. Shelley \& Peplau, Letitia Anne; David O, Sears, Psikologi Sosial (edisi kedua belas), Jakarta : Kencana Prenada Media Group, 2009.

Yusuf . LN. Syamsu. Psikologi Perkembangan anak dan Remaja, Bandung: PT. Remaja Rosdakarya, 2005. 